\title{
Why do I talk about "Therapeutic writing"? What are the reasons that push me to do so?
}

\author{
Sonia Scarpante* \\ President Association La cura di sé Piazza dell' Assunta 1A 20141 Milano, Italy \\ Received: 阱July 28, 2018; Published: 橎 August 07, 2018 \\ *Corresponding author: Sonia Scarpante, president Association La cura di sé Piazza dell' Assunta 1A 20141 Milano, Italy
}

\section{Opinion}

I talk of Therapeutic writing because my start of a new life begins just from my autobiography "Lettered ad un interlocutor real". My meaning through which I've learnt many things about life.

\section{What has this autobiographical walk taught me?}

I've learnt that "Writing" is a powerful mean, a fundamental help for the ones who are looking for a better inside balance. I call it "Therapeutic" because, with a continuous work of a repairing writing, it turns out how much it can help us to recover from the most important sorrows, to cope with traumatic events, to dissolve our knots, to solve our emotional fragility. To win old guilts. Thanks to my writing, I have learnt to compare myself, I've learnt to consider my emotions and let them speak, without fear. The "Therapeutic writing", meant as individual and practical research, increases our internal strength, therefore makes the quality of our life better.

Again, the "Therapeutic writing" can be considered one of the cognitive instruments, nor the last neither the resolving one, but useful to learn how to sustain ourselves. The process of the "T.W.", in the first place individual and then shared with others, can develop a more sensitive attention, a more considerate sensitiveness for other lives and experiences, where trust becomes the essential element. "The Writing "as analysis of myself, was born then from my first autobiographical work published in 2003. A hard work and really efficient where the compulsive writing gives rules with a pressing and pressing cadence, anticipating even the thoughts. That initial writing has stimulated the auto-analysis from which considerations of cognitive and emotional interest have surfaced. Through the autobiographical writing I've learnt to reveal myself in every detail, I've learnt to recover the relationships, to dissolve dangerous existential knots, to discover and solve guilts, to reconcile myself with those difficult events of my life, hidden in my past.

In this kind of work two peculiarities are essential, both will help us to elaborate and distinguish, to have courage in analysing ourselves and to be trustful in what we are going to build. The "T.W." is an introspective and demanding trip that is able to give us new opportunities to listen and to know ourselves better, a travel that will take us to new and unimaginable roads. During this introspective travel we can learn to talk of emotions and feelings without being judged, to discover in other stories analogies with ours, to share our suffering becoming more aware. Writing about ourselves and then looking at ourselves from different perspective thanks to the exchange with the other participants and the coach's suggestions, gets a well-being and reawakens personal resources forgotten or hidden, up until now. With the "T.W." the trip has as target the personal development and self-determination that takes shape inside a group of people. In this group everybody is invited to write letters, the first one addressed to oneself (practical methodology taken from "Parole evolute" published by Edi Science).

Other letters addressed to our interlocutors and relatives will follow, letters concerning fears or specific situations that we often must face, as well. The first and most important step is to be able to accept ourselves, to forgive and love ourselves. In this sense the "T.W" is an introspective discipline. In medical field this method of writing is called "adjuvant therapy" and it's suggested together with the pharmacological one as a valid psychological help for the patient. The personal benefits coming from the "writing work", individually made, get a happy correspondence when shared and read during the encounters: in these cases you'll not find prejudices. A sense of emotional involvement and acceptance of the group will give a further willing of change to the person in his own contest of life. The "writing" allows him to feel and see himself as a protagonist of a different reality.

Then the psychological relevance to foresee a change, to find a new image of ourselves, to foresee a "authentic myself" that has to be discovered and rebuilt. We can state that the "writing" is a kind of emancipation, a valid help to build a future of people more satisfied and aware. Is it possible that the "T.W." turns out as "Formative writing"? If so, what are the aspects that cannot be neglected? To dig up in parents' memories, for example, is fundamentally important, the theme of our own identity, the relationship with our children, with our partner. To dig up in our own dreams, difficulties, but also a writing that let us develop a sort of analysis of ourselves. In this way the "T.W. can turn out as a "Formative writing." As I write in my book PAROLE EVOLUTE, ESPERIENZE E TECNICHE DI SCRITTURA 
TERAPEUTICA.... I know how much to think about these contents can cost in emotional terms and self-examination, but I know very well, because I myself lived them, also the benefits you can reach, once you have been so brave to face problems with the aid of the written word ....

\section{ISSN: 2574-1241}

DOI: 10.26717/BJSTR.2018.07.001538

Sonia Scarpante. Biomed J Sci \& Tech Res

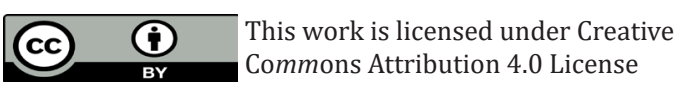

Submission Link: https://biomedres.us/submit-manuscript.php

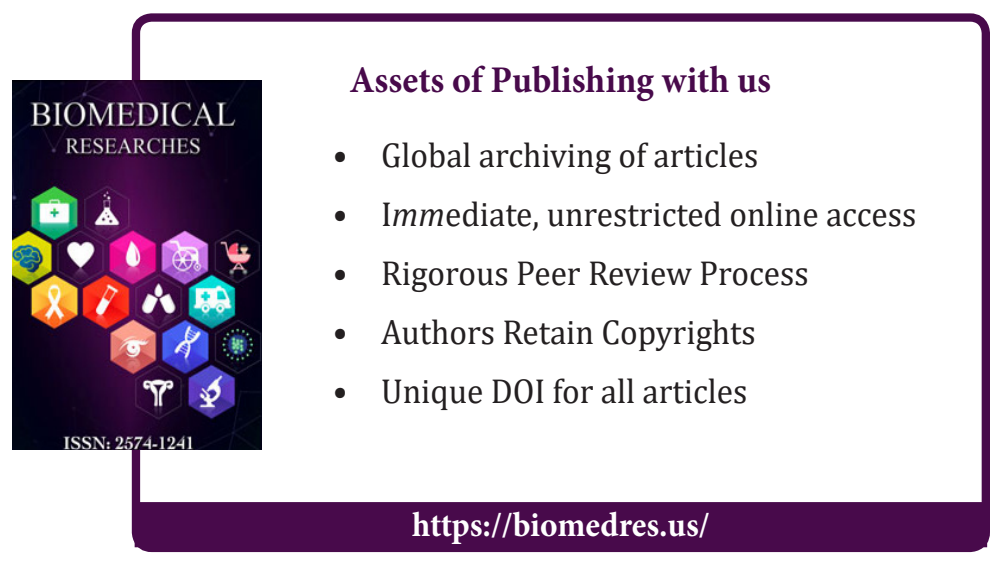

